\title{
Separating the Effects of Foliar and Root Salt Uptake on Growth and Mineral Composition of Four Grapevine Cultivars on their Own Roots and on 'Ramsey' Rootstock
}

\author{
Rob M. Stevens \\ Primary Industries South Australia, Loxton Centre, PO Box 411, Loxton 5333, Australia \\ Gordon Harvey \\ South Australian Research and Development Institute, Loxton Centre, PO Box 411, \\ Loxton 5333, Australia \\ Gerry Davies \\ Primary Industries South Australia, Lenswood Centre, Swamp Road, Lenswood 5240, Australia \\ Additional index words. Vitis vinifera, Vitis champini, foliar absorption, root absorption, sodium chloride
}

\begin{abstract}
The effect of foliar salt uptake on potted grapevine growth and ionic composition was investigated in a split plot trial. The main plot was a $2 \times 2$ factorial consisting of separately irrigating the roots and foliage with nonsaline or saline $(25 \mathrm{~mm} \mathrm{NaCl})$ solutions. The subplot was a $4 \times 2$ factorial consisting of four grape (Vitis vinifera) cultivars on their own roots or ' $R$ amsey' (Vitis champini) rootstock. Saline foliar irrigation over 27 weeks reduced total vine growth by $14 \%$ while saline root irrigation had no effect. Leaf $\mathrm{Na}$ and $\mathrm{Cl}$ concentrations were elevated by saline foliar and saline root irrigation. The increases in concentrations with saline foliar irrigation were four times those with saline root irrigation. Leaf $K$ concentration was reduced by saline foliar irrigation and increased by saline root irrigation. With saline irrigation of roots and foliage the Cland $\mathrm{Na}$ levels were highest in the leaves of 'Shiraz', but with saline irrigation of only the roots 'Sultana' had the higher levels of leaf Cl and 'Shiraz' the highest leaf $\mathrm{Na}$. Saline foliar irrigation had no effect on the concentrations of $\mathrm{Na}, \mathrm{Cl}$, and $\mathrm{K}$ in the roots. In 'Sultana', saline foliar irrigation did not affect the leaf concentrations of $\mathrm{N}, \mathrm{NO}_{3}-\mathrm{N}, \mathrm{P}, \mathrm{Mg}, \mathrm{Zn}$, and $\mathrm{Cu}$. It increased the leaf concentration of $\mathrm{Fe}$, and decreased that of Mn. Rootstock modified the effect of salinity on Fe concentrations. The B concentration was decreased by saline irrigation of either the foliage or the roots, but not by saline irrigation of both. In roots, saline foliar irrigation increased B in own-rooted vines, but not in those on 'Ramsey' rootstock.
\end{abstract}

The Murray Darling Basin is a major horticultural production area in Australia and in its southern portion the irrigation water salinity reaches $1.0 \mathrm{dS} / \mathrm{m}$ with a $\mathrm{NaCl}$ concentration of about $8 \mathrm{~mm}$ (McKay et al., 1988). Seasonal overhead sprinkler operations are in excess of 120 hours. Under these conditions, it is likely that the foliar uptake of salt contributes to salinity damage.

Prior et al. (1992a) suggested that the yield loss in salinized vines was caused by a decrease in photosynthesis. They found that leaf photosynthesis was strongly negatively correlated with leaf $\mathrm{Cl}$ concentration. Ehlig (1960) demonstrated that the accumulation of $\mathrm{Cl}$ in leaves caused foliar damage. Along the River Murray, Prior and Grieve (1985) found the leaf $\mathrm{Cl}$ concentration in vineyards irrigated with overhead sprinklers was $16 \%$ higher than that in vineyards where irrigation was applied by under canopy methods.

Francois and Clark (1979) found the leaf $\mathrm{Cl}$ and $\mathrm{Na}$ concentrations in vines sprinkled with saline water were directly proportional to the total sprinkling time. After $54 \mathrm{~h}$ of sprinkling with 10 $\mathrm{mm} \mathrm{NaCl}$, the leaf concentrations of $\mathrm{Na}$ and $\mathrm{Cl}$ approached toxic levels.

Amongst table grape cultivars, Francois and Clark (1979) found foliar $\mathrm{Na}$ and $\mathrm{Cl}$ uptake varied with cultivar. Downton

Received for publication 10 July 1995. Accepted for publication 7 Dec. 1995. We thank Phil Cole and Peter Magarey for commenting on the manuscript; Tony Bass for glasshouse operation; Alison Frensham for statistical advice; Grape and Wine Research and Development Corporation and CCW Co-operative Limited for financial assistance; Pilon Plastics, Sydney, for providing closed cell foam. The use of trade names in this publication does not imply endorsement by PI SA of products, nor criticism of similar ones not mentioned. The cost of publishing this paper was defrayed in part by the payment of page charges. Under postal regulations, this paper therefore must be hereby marked advertisement solely to indicate this fact.
(1977) found that $\mathrm{Na}$ and $\mathrm{Cl}$ uptake by the roots was dependent on the rootstock species.

This study aimed to separate the effects on grapevine growth and tissue composition of salt uptake by the foliar pathway from those by the root pathway and to determine the effects of four winegrape cultivars on their own roots and on 'Ramsey' rootstock on this apportionment.

\section{Materials and Method}

Plantmaterial and culture. Cuttings of own-rooted 'Chardonnay', 'Sultana', 'Ruby Cabernet', and 'Shiraz' vines and scions of these same four cultivars, which had been bench grafted onto 'Ramsey' rootstock, were planted in 2-liter pots and grown in shadehouse in the 1991-92 season (southern hemisphere).

In mid-August 1992, the dormant vines were pruned to two bud spurs and the potting soil was teased away from the roots while they were immersed in water. Five randomly selected vines from each cultivar-rootstock combination were harvested, divided into root and stem, and dried to a constant weight at $70 \mathrm{C}$. The remaining vines were repotted in 4-liter pots filled with steam sterilized coarse washed sand and placed in a $70 \%$ shaded glasshouse where the temperature was maintained between 15 and 30C. Budburst occurred on 8 Sept. and after a single shoot of six leaves had established, the other buds were rubbed off. The shoot was trellised to a string suspended between the bench base and a mesh $2 \mathrm{~m}$ above. By mid-October, the vines had grown to a height of $1.5 \mathrm{~m}$. Subsequent growth above this height and lateral shoots greater than two nodes in length were pruned monthly and retained for measurement of dry weight.

The vine roots were irrigated by a dripper in each pot with each 
vine receiving 0.17 liter of irrigation five times per day. The irrigation was well in excess of the soil water deficit and pots began to drain before the end of each irrigation. Irrigation water consisted of water drawn from the River Murray to which a commercial hydroponic solution (Hydroponic Nutrients, Top Australia, Adelaide, Australia) was added to bring the nutrient concentration to one-tenth of that recommended by the manufacturer. The resultant concentrations of $\mathrm{N}, \mathrm{P}, \mathrm{K}, \mathrm{Ca}, \mathrm{Mg}$, and $\mathrm{S}$ in the irrigation water were $1.5,0.1,0.6,0.8,0.7$, and $0.6 \mathrm{~mm}$, respectively. Iron concentration was raised to $1 \mathrm{mg} \cdot \mathrm{liter}^{-1}$ by addition of sodium ferric ethylenediamine di (O-hydroxy phenylacetate). In midNovember the vines received a foliar spray consisting of 0.4 and $0.3 \mathrm{~g} \cdot$ liter $^{-1}$ of $\mathrm{Zn}$ and $\mathrm{Mn}$ as sulphate salts, and $6 \mathrm{~g} \cdot \mathrm{liter}^{-1}$ of urea. Growth increased with the onset of longer days and in November the nutrient additions to the irrigation water were doubled.

Vine foliage was irrigated with inverted microjet sprinklers suspended $2 \mathrm{~m}$ above the bench. Overhead irrigation was scheduled with a frequency and duration similar to that found in local commercial vineyards i.e., a $10.5 \mathrm{~h}$ irrigation being applied every 14 days with irrigation beginning at $1600 \mathrm{HR}$. The volumes of irrigation water were measured by in-line flow meters.

Treatment. The trial was a split plot design with the main plot a two by two factorial of irrigation treatments (combinations of plus $(+S)$ or minus $(-S)$ salt in the foliar $(F)$ and $\operatorname{root}(R)$ irrigation solutions) and the subplot a four by two factorial (combinations of four cultivars, 'Chardonnay', 'Shiraz', 'Ruby Cabernet' and 'Sultana', on their own-roots or 'Ramsey' rootstock). The trial consisted of five replicates. Each replicate occupied a bench with a row of barrier vines placed around its perimeter.

Both the foliar and root irrigation solutions were salinised by addition of a sodium and calcium chloride brine to bring the irrigation solution $\mathrm{NaCl}$ concentration to $25 \mathrm{~mm}$ and the $\mathrm{Na}: \mathrm{Ca}$ molar ratio to $17: 1$. Root saline irrigation began at budburst and saline foliar irrigation began 1 day after budburst - both continued until harvest.

Contamination of the rootzone by foliar solution was prevented by two barriers to water movement attached to the base of each stem. Each barrier consisted of a collar made from a strip of $2 \mathrm{~mm}$ closed cell foam wrapped four times around the stem and held in place with waterproof double sided tape to which was attached a plastic sheet fabricated into a cone. The top of the cone was attached to the collar with waterproof cloth tape. The plastic cone flared downward to below the top of the pot. On the top barrier, a waterproof pruning paint was applied as an additional seal against water movement between the collar and the stem. In the grafted vines, the graft and the stem of the rootstock, which protruded above the collar, were also coated with waterproof pruning paint to prevent salt entry via these sites.

Cross contamination of plots during overhead sprinkling was prevented by inserting movable 2-m-deep plastic curtains, which fell from the top of the trellis to the base of the pots, between the plots.

Water samples were collected by continuously bleeding the supply line through a microcapillary tube into a 4-liter jar. These samples were bulked on a monthly basis and analysed for $\mathrm{Na}$ and $\mathrm{Cl}$ following methods described for analysis of tissue.

Measurements. In mid-March, the vines were harvested and the shoots divided into leaves and stems. Roots were separated from the potting sand by submerging the pots in water and teasing the sand away from the root balls. Roots that broke away from the balls were retrieved from the washing water with a sieve. All material was dried to a constant weight at 70C. The stem and root portions included growth from the preceding season. So that the weights represented only growth that occurred during the trial, the weights of these two portions were corrected by subtracting the mean weights of the root and stem samples taken at the beginning of the trial before budburst.

Chemical analyses were performed on the lamina of leaves inserted between nodes three and eleven, and on a subsample of roots removed after the entire root sample was coarsely ground. At harvest, the leaves were rinsed in three 5-liter baths of distilled water to remove salt from their surface. Two drops of $5 \mathrm{~N}$ nitric acid and two drops of phosphate-free detergent were added to the first bath. The water was changed whenever the electrical conductivity of the first bath rose above $0.1 \mathrm{dS} \cdot \mathrm{m}^{-1}$. After drying, the material was ground in a hammer mill to pass a $0.8 \mathrm{~mm}$ mesh. Chloride content of a cold water extract was measured with a chloridometer. The remaining material was ashed, dissolved in $6 \mathrm{~N} \mathrm{HCl}$, and the $\mathrm{Na}$ and $\mathrm{K}$ was measured by atomic absorption spectrophotometry (Leece and Short, 1967). For 'Sultana', leaf lamina and root concentrations of $\mathrm{N}, \mathrm{NO}_{3}-\mathrm{N}, \mathrm{P}, \mathrm{Mg}, \mathrm{Ca}, \mathrm{Fe}, \mathrm{Zn}, \mathrm{Mn}, \mathrm{Cu}$, and $\mathrm{B}$ were also determined. The determination of cations followed the method already described. Nitrate-N was determined by an ion selective electrode in a cold water extract buffered with $\mathrm{Al}_{2}\left(\mathrm{SO}_{4}\right)_{3}$; nitrogen was measured on a modified Kjeldahl digest; phosphorus was measured by the molybdenum blue method (Murphy and Riley, 1962); boron was measured by the carminic acid method (Hatcher and Wilcox, 1950).

Statistical analysis. The significance of difference between treatments was tested by analysis of variance. Least significant differences were only calculated when the F test for treatments was

Table 1. The effects of saline $(+S)$ foliar $(F)$ and root $(R)$ irrigation on the net grapevine growth (g/vine).

\begin{tabular}{|c|c|c|c|c|c|c|c|}
\hline & \multicolumn{4}{|c|}{ Irrigation treatment } & \multicolumn{3}{|c|}{$\operatorname{LSD}(P=0.05)$} \\
\hline & F-S, R-S & $\mathrm{F}-\mathrm{S}, \mathrm{R}+\mathrm{S}$ & $\mathrm{F}+\mathrm{S}, \mathrm{R}-\mathrm{S}$ & $\mathrm{F}+\mathrm{S}, \mathrm{R}+\mathrm{S}$ & F & $\mathrm{R}$ & $\mathrm{F} \times \mathrm{R}$ \\
\hline$\overline{\operatorname{Root}^{2}}$ & 16.1 & 14.4 & 12.5 & 9.2 & 1.9 & 1.9 & NS \\
\hline Stem $^{\mathrm{y}}$ & \multicolumn{2}{|c|}{46.7} & \multicolumn{2}{|c|}{40.9} & 3.3 & NS & NS \\
\hline Leaf $^{x}$ & 34.5 & 40.1 & 32.4 & 34.2 & $* * *$ & $* * *$ & 4.3 \\
\hline Total $^{\mathrm{y}}$ & \multicolumn{2}{|c|}{100.1} & \multicolumn{2}{|c|}{85.8} & 6.3 & NS & NS \\
\hline
\end{tabular}

${ }_{\mathrm{z}}$ The effect of each factor was significant, but the interaction between them was not, the individual treatment means are shown and application of the LSD requires calculation of the mean appropriate to the comparison.

${ }^{\mathrm{T}}$ The effect of saline foliar irrigation was significant and the mean appropriate for comparison is shown.

xThe effect of each factor and the interaction between factors were significant; the significance of the effect of individual factors, and the LSD and means appropriate to comparison based on the interaction between factors are shown. 
significant. Tukey's one degree of freedom test for non-additivity was used to test for the assumption of additivity, and the assumption of normality was checked by inspection of the plot of fitted values against residuals. Where necessary, the data were log transformed to meet assumptions of normality and additivity.

\section{Results}

The mean concentrations of $\mathrm{NaCl}$ were 3.3 and $26.0 \mathrm{~mm}$ for the nonsaline and saline solution, respectively. Analysis of the variance amongst the sets of samples collected on a monthly basis showed that the $\mathrm{Na}$ and $\mathrm{Cl}$ concentrations in the foliar and root irrigation were equivalent.

Growth. The effects of saline irrigation on the growth of whole vine and individual organs were independent of vine cultivar and rootstock. Saline foliar irrigation depressed total vine growth by $14 \%$, root growth by $28 \%(\mathrm{~F}+\mathrm{S}$ vs. F-S $)$, stem growth by $12 \%(\mathrm{~F}+\mathrm{S}$ vs. F-S) and leaf growth by $11 \%$ (Table 1). Saline root irrigation did not affect the total vine growth. It depressed root growth by $17 \%(\mathrm{R}+\mathrm{S}$ vs. R-S), did not affect stem growth and stimulated leaf growth by $11 \%(\mathrm{R}+\mathrm{S}$ vs. $\mathrm{R}-\mathrm{S})$. The $11 \%$ increase was due to the positive effect that saline root irrigation had on leaf growth when foliar irrigation was nonsaline (F-S,R+S vs. F-S,R-S).

Leaf $\mathrm{Cl}, \mathrm{Na}$, and $\mathrm{K}$ concentrations. In the treatment combining saline foliar irrigation with nonsaline root irrigation, the $\mathrm{Cl}$ and $\mathrm{Na}$ concentrations were $208 \%$ and $519 \%$, respectively greater than those in the nonsaline control (Table 2). Saline root irrigation caused smaller increases relative to the control. In the treatment combining nonsaline foliar with saline root irrigation, the $\mathrm{Cl}$ and Na concentrations were $59 \%$ and $109 \%$, respectively, greater than those in the nonsaline control. The rises in $\mathrm{Cl}$ and $\mathrm{Na}$ concentrations caused by saline foliar irrigation were 3.7 and 4.7 times those caused by saline root irrigation.

'Ramsey' rootstock reduced the $\mathrm{Cl}$ concentration in all irrigation treatments (Table 2). The reduction of $48 \%$ achieved under nonsaline conditions was much greater than that of $18 \%$ and $10 \%$ achieved under saline root and saline foliar irrigation treatments, respectively. 'Ramsey' rootstock reduced the Na concentration in the nonsaline control, had no effect in irrigation treatments that received saline foliar irrigation, and increased the Na concentration in the treatment combining saline root irrigation with nonsaline foliar irrigation.

Table 2. The effects of saline $(+\mathrm{S})$ foliar $(\mathrm{F})$ and root $(\mathrm{R})$ irrigation on the concentrations of $\mathrm{Cl}$ and $\mathrm{Na}$ in the leaves of grapevines on their ownroots and 'Ramsey' rootstock. Data were log transformed for analysis and the untransformed values of concentration ( $\mathrm{mmol} \cdot \mathrm{kg}^{-1}$ dry weight) are enclosed in parenthesis.

\begin{tabular}{llccc}
\hline \hline & \multicolumn{4}{c}{ Irrigation treatment } \\
\cline { 2 - 5 } & $\mathrm{F}-\mathrm{S}, \mathrm{R}-\mathrm{S}$ & $\mathrm{F}-\mathrm{S}, \mathrm{R}+\mathrm{S}$ & $\mathrm{F}+\mathrm{S}, \mathrm{R}-\mathrm{S}$ & $\mathrm{F}+\mathrm{S}, \mathrm{R}+\mathrm{S}$ \\
\hline \multirow{4}{*}{ Chloride } \\
Own-rooted & $2.29(198)$ & $2.40(260)$ & $2.68(487)$ & $2.70(502)$ \\
Ramsey & $2.01(103)$ & $2.31(212)$ & $2.64(437)$ & $2.66(468)$
\end{tabular}

LSD $0.03(P=0.05)$ for comparison between rootstock species receiving the same irrigation treatments and for comparison between different irrigation treatments with the same or different rootstock species.

\section{Sodium}

$\begin{array}{lllll}\text { Own-rooted } & 1.63(48) & 1.81(77) & 2.37(261) & 2.48(336)\end{array}$ Ramsey $\quad 1.55(37) \quad 1.97(102) \quad 2.38(270) \quad 2.52$ (355) LSD $0.05(P=0.05)$ for comparison between rootstock species receiving the same irrigation treatments: $0.07(P=0.05)$ for comparison between different irrigation treatments with the same or different rootstock species.
Table 3. The effects of saline $(+\mathrm{S})$ foliar $(\mathrm{F})$ and root $(\mathrm{R})$ irrigation on the concentrations of $\mathrm{Cl}$ and $\mathrm{Na}$ in the leaves of four grapevine cultivars. Data was log transformed for analysis and the untransformed values of concentration $\left(\mathrm{mmol} \cdot \mathrm{kg}^{-1}\right.$ dry weight) are enclosed in parenthesis.

\begin{tabular}{lcccc}
\hline \hline & \multicolumn{4}{c}{ Irrigation treatment } \\
\cline { 2 - 5 } & F-S, R-S & F-S, R+S & F+S, R-S & F+S, R+S \\
\hline \multirow{4}{*}{ Chardonnay } & $2.14(144)$ & $2.30(205)$ & $2.57(372)$ & $2.63(432)$ \\
Sultana & $2.17(166)$ & $2.46(294)$ & $2.70(499)$ & $2.66(463)$ \\
Ruby Cabernet & $2.18(153)$ & $2.36(238)$ & $2.64(434)$ & $2.66(457)$ \\
Shiraz & $2.11(139)$ & $2.31(206)$ & $2.73(542)$ & $2.77(590)$
\end{tabular}

LSD $0.10(P=0.05)$ for comparison between cultivars in the same irrigation treatment: $0.05(P=0.05)$ for comparison between irrigation treatments with the same or different cultivar.

\begin{tabular}{lcccc} 
& \multicolumn{5}{c}{ Sodium } \\
Chardonnay & $1.43(28)$ & $1.73(56)$ & $2.23(173)$ & $2.39(256)$ \\
Sultana & $1.63(44)$ & $1.92(86)$ & $2.42(268)$ & $2.50(317)$ \\
Ruby Cabernet & $1.57(44)$ & $1.75(60)$ & $2.21(165)$ & $2.37(239)$ \\
Shiraz & $1.73(54)$ & $2.17(156)$ & $2.65(453)$ & $2.74(569)$
\end{tabular}
LSD $0.12(P=0.05)$ for comparison between irrigation treatments with the same or different cultivar: $0.10(P=0.05)$ for comparison between cultivars receiving the same irrigation treatment.

There were significant interactions between irrigation and cultivars for the $\mathrm{Cl}$ and $\mathrm{Na}$ concentrations. With saline irrigation of the foliage and the roots, the $\mathrm{Cl}$ concentration in 'Shiraz' vines was greater than the other cultivars. With the treatment that combined saline root irrigation and nonsaline foliar irrigation, the $\mathrm{Cl}$ concentration in 'Sultana' was greater than all other cultivars. With nonsaline irrigation all cultivars were equivalent (Table 3 ).

In all irrigation treatments, the Na concentration in 'Shiraz' was higher than in 'Sultana', which in turn was higher than in 'Chardonnay' and 'Ruby Cabernet', which were equivalent excepting the nonsaline treatment (Table 3 ). With the combination of saline foliar and saline root irrigation the greatest increase (linear scale) in Na occurred in 'Shiraz' and 'Chardonnay', 954\% and $814 \%$ respectively. Even though a large increase in Na occurred in 'Chardonnay', the concentration was equivalent to that in 'Sultana', the cultivar with the lowest concentration, because the base level of $\mathrm{Na}$ in 'Chardonnay' was the lowest amongst cultivars. In the treatment that combined saline root irrigation with nonsaline foliar irrigation, the greatest increase in Na concentration, $189 \%$, occurred in 'Shiraz'. With saline foliar irrigation, the addition of saline root irrigation caused a rise in the $\mathrm{Na}$ concentrations of 'Chardonnay' and 'Ruby Cabernet', but had no effect on those of 'Sultana' and 'Shiraz'.

Saline foliar irrigation decreased $(P<0.001)$ the K concentration by $15 \%$ from 351 to $297 \mathrm{mmol} \cdot \mathrm{kg}^{-1}$ dry weight. This effect was independent of the root irrigation treatment, cultivar, and rootstock. Saline root irrigation increased the K concentration by $60 \%$ from 250 to $397 \mathrm{mmol} \cdot \mathrm{kg}^{-1}$ dry weight, and altered the ranking of cultivars by K concentration (Table 4). With saline root irrigation the K concentrations in 'Sultana' and 'Ruby Cabernet' were higher than those in 'Chardonnay' and 'Shiraz'. Under nonsaline root irrigation the K concentration in 'Sultana' was higher than those in other cultivars. The interaction term between foliar and root irrigation was not significant, however there was a trend $(P<0.10)$ for the $\mathrm{K}$ concentrations in the treatment combining saline root irrigation with nonsaline foliar irrigation, $436 \mathrm{mmol} \cdot \mathrm{kg}^{-1}$ dry weight, and the treatment receiving saline irrigation of the foliage and roots, $360 \mathrm{mmol} \cdot \mathrm{kg}^{-1}$ dry weight, to be higher than that in the 
Table 4. The effect of saline $(+\mathrm{S})$ root irrigation treatment on the $\mathrm{K}$ concentration $\left(\mathrm{mmol} \cdot \mathrm{kg}^{-1}\right.$ dry weight) in the leaves of four grapevine cultivars

\begin{tabular}{lcc}
\hline \hline Root irrigation treatment & $\mathrm{R}-\mathrm{S}$ & $\mathrm{R}+\mathrm{S}$ \\
\hline Chardonnay & 227 & 361 \\
Sultana & 287 & 441 \\
Ruby Cabernet & 240 & 437 \\
Shiraz & 246 & 352
\end{tabular}

LSD $42(P=0.05)$ for comparison between different root irrigation treatments with the same or different cultivars: $38(P=0.05)$ for comparison between two cultivars receiving the same root irrigation treatment.

nonsaline control treatment, $266 \mathrm{mmol} \cdot \mathrm{kg}^{-1}$ dry weight.

Root $\mathrm{Cl}, \mathrm{Na}$, and $\mathrm{K}$ concentrations. The salinity of foliar irrigation did not affect the concentrations of $\mathrm{Na}, \mathrm{Cl}$, and $\mathrm{K}$ in the root (data not shown).

Saline root irrigation increased the concentration of $\mathrm{Cl}$ and this effect was modified by rootstock and cultivar. In 'Sultana' and 'Shiraz', the use of 'Ramsey' rootstock reduced the Cl concentration regardless of root irrigation treatment. With 'Chardonnay' the rootstock only reduced the $\mathrm{Cl}$ concentration under saline irrigation. In contrast, the use of 'Ramsey' rootstock with 'Ruby Cabernet' increased the $\mathrm{Cl}$ concentration under saline conditions (Table 5).

With saline root irrigation the use of 'Ramsey' rootstock decreased the root concentration of $\mathrm{Na}$ in 'Sultana', had no effect in 'Chardonnay', and increased it in 'Ruby Cabernet' and 'Shiraz' (Table 5). With nonsaline root irrigation, 'Ramsey' rootstock did not affect $\mathrm{Na}$.

Saline root irrigation decreased $(P=0.0001)$ the K concentration in 'Shiraz' from 230 to $157 \mathrm{mmol} \cdot \mathrm{kg}^{-1}$ dry weight. It did not affect the concentrations in 'Sultana', 'Ruby Cabernet', and 'Chardonnay', which were 263,196 , and $208 \mathrm{mmol} \cdot \mathrm{kg}^{-1}$ dry weight, respectively. In own-rooted vines, saline root irrigation decreased $(P=0.01)$ the concentration of $\mathrm{K}$ from 263 to $223 \mathrm{mmol} \cdot \mathrm{kg}^{-1}$ dry weight. The $\mathrm{K}$ concentration in 'Ramsey' rootstock did not respond to saline irrigation and had a mean value of $198 \mathrm{mmol} \cdot \mathrm{kg}^{-1}$ dry weight.

Leaf $\mathrm{P}, \mathrm{Mg}, \mathrm{Mn}, \mathrm{B}, \mathrm{Fe}, \mathrm{Ca}, \mathrm{N}, \mathrm{NO}_{3}-\mathrm{N}, \mathrm{Zn}$, and Cu concentrations. Saline foliar irrigation decreased $(P=0.02)$ the concentration of $\mathrm{Mn}$ from 15.3 to $13.7 \mathrm{mmol} \cdot \mathrm{kg}^{-1}$ dry weight and increased $(P<0.0001)$ the concentration of Fe from 0.54 to $0.71 \mathrm{mmol} \cdot \mathrm{kg}^{-1}$ dry weight. With nonsaline foliar irrigation, the use of 'Ramsey' rootstock decreased $(P<0.01)$ Fe concentration from 0.45 to $0.30 \mathrm{mmol} \cdot \mathrm{kg}^{-1}$ dry weight.

In own-rooted vines, saline foliar irrigation increased $(P<0.05)$ the concentration of $\mathrm{Ca}$ from 591 to $664 \mathrm{mmol} \cdot \mathrm{kg}^{-1}$ dry weight. This increase may have been caused by the addition of $\mathrm{Ca}$ to the saline irrigation solutions, however with vines on 'Ramsey' rootstock the $\mathrm{Ca}$ concentration was not affected by the salinity of irrigation and had a mean value of $676 \mathrm{mmol} \cdot \mathrm{kg}^{-1}$ dry weight.

In the nonsaline control treatment and that receiving saline irrigation of the foliage and roots, the $\mathrm{B}$ concentrations were equivalent with a mean value of $8.4 \mathrm{mmol} \cdot \mathrm{kg}^{-1}$ dry weight. In the treatments where saline irrigation was only applied to the foliage or to the roots, B was reduced $(P<0.002)$ to 7.5 and $7.1 \mathrm{mmol} \cdot \mathrm{kg}^{-1}$ dry weight for saline foliar and saline root irrigation, respectively. The concentrations of $\mathrm{B}$ in these two treatments were equivalent.

Saline root irrigation decreased $(P<0.001)$ the concentration of $\mathrm{Mg}$ from 205.0 to $168.0 \mathrm{mmol} \cdot \mathrm{kg}^{-1}$ dry weight and increased $(P=$ $0.001)$ the concentration of $P$ from 191 to $398 \mathrm{mmol} \cdot \mathrm{kg}^{-1}$ dry weight.

The irrigation treatments did not affect the concentrations of $\mathrm{N}$, $\mathrm{NO}_{3}-\mathrm{N}, \mathrm{Zn}$ and $\mathrm{Cu}$ and their means were 2075, 36, 4.9, and 0.3 $\mathrm{mmol} \cdot \mathrm{kg}^{-1}$ dry weight, respectively.

Root $\mathrm{P}, \mathrm{Mg}, \mathrm{Mn}, \mathrm{B}, \mathrm{Fe}, \mathrm{Ca}, \mathrm{N}, \mathrm{NO}_{3}-\mathrm{N}, \mathrm{Zn}$, and $\mathrm{Cu}$ concentrations. In own-rooted vines, saline foliar irrigation increased the concentration of B from 1.3 to $1.7 \mathrm{mmol} \cdot \mathrm{kg}^{-1}$ dry weight $(P=0.05)$. The concentration in 'Ramsey' rootstock was not affected by the salinity of irrigation and had a mean value of $1.7 \mathrm{mmol} \cdot \mathrm{kg}^{-1}$ dry weight.

Saline root irrigation increased $(P=0.01)$ the concentration of $\mathrm{P}$ from 93 to $141 \mathrm{mmol} \cdot \mathrm{kg}^{-1}$ dry weight and 85 to $108 \mathrm{mmol} \cdot \mathrm{kg}^{-1}$ dry weight in 'Sultana' roots and 'Ramsey' rootstock, respectively. With saline root irrigation the $\mathrm{P}$ concentration in 'Sultana' roots was greater $(P=0.01)$ than that in 'Ramsey' rootstock.

Saline root irrigation increased the concentrations of $\mathrm{Mn}(P<$ $0.0001)$ and $\mathrm{Fe}(P=0.02)$ from 3 to $6 \mathrm{mmol} \cdot \mathrm{kg}^{-1}$ dry weight and 28 to $37 \mathrm{mmol} \cdot \mathrm{kg}^{-1}$ dry weight, respectively. The concentration of $\mathrm{Mg}$ was reduced $(P=0.0001)$ from 99 to $80 \mathrm{mmol} \cdot \mathrm{kg}^{-1}$ dry weight by saline root irrigation.

The irrigation treatments did not affect the concentrations of $\mathrm{N}$, $\mathrm{NO}_{3}-\mathrm{N}, \mathrm{Ca}, \mathrm{Zn}$, and $\mathrm{Cu}$ and their mean concentrations were 1329 , $75,139,3.1$, and $0.6 \mathrm{mmol} \cdot \mathrm{kg}^{-1} \mathrm{~g}$ dry weight, respectively.

\section{Discussion}

Growth. The effects of salinity on growth have been ascribed to osmotic and toxic ion stresses, and nutrient imbalance (Marschner, 1986). Saline root irrigation did not reduce vine growth and therefore the growth loss in the present study could not be attributed to a fall in the osmotic potential of the soil solution.

Saline foliar irrigation decreased the leaf Mn and K concentrations by $10 \%$ and $15 \%$, respectively, and increased the Fe concentration by $32 \%$. While saline foliar irrigation decreased $\mathrm{K}$ in the leaf, there was a trend in the treatment combining saline root with saline foliar irrigation for the concentration to be greater than that in the nonsaline control treatment which suggests that a reduction in leaf $\mathrm{K}$ cannot explain the loss in growth. In own-rooted vines, but not those on 'Ramsey' rootstock, saline foliar irrigation increased the lamina concentration of $\mathrm{Ca}$ and the root concentration of $\mathrm{B}$. The growth loss was unresponsive to rootstock and this suggests that alterations to the Ca content of the lamina and the B content of the roots did not affect growth. Saline foliar irrigation decreased the B concentration of leaves in the absence of saline root irrigation, but not in its presence. The loss of growth was insensitive to the salinity of root irrigation suggesting that the growth loss could not be attributed to alteration of the $\mathrm{B}$ concentration.

By elimination, the remaining potential causative agents of growth decline are the toxic effects of $\mathrm{Na}$ and $\mathrm{Cl}$ and the nutritional disorders caused by decreasing Mn or increasing Fe. The percentage changes in the concentrations of $\mathrm{Na}$ and $\mathrm{Cl}(>200 \%)$ were much greater than those in the concentrations of $\mathrm{Mn}$ and $\mathrm{Fe}$ and there differences suggest a toxic effect rather than a nutrient disorder was the more likely cause of the growth loss.

Walker et al. (1981) found that the suppression of shoot growth in 'Sultana' vines by saline irrigation of the rootzone $(90 \mathrm{~mm} \mathrm{NaCl})$ could be fully reversed by replacing the saline irrigation solution with nonsaline solution. The leaf concentrations of $\mathrm{Na}$ and $\mathrm{Cl}$ remained high during this recovery. Their observation would support a hypothesis that high tissue concentrations of a $\mathrm{Na}$ and $\mathrm{Cl}$ are not necessarily toxic and are only associated with a decline in growth when roots are irrigated with saline solutions i.e., the vine is exposed to an osmotic stress due to the lowering of soil water potential by saline irrigation. In the present study, the association between reduced growth, high leaf $\mathrm{Na}$ and $\mathrm{Cl}$ concentrations, and nonsaline root irrigation found in the treatment combining saline 
Table 5. The effect of root irrigation treatment on the concentrations ( $\mathrm{mmol} \cdot \mathrm{kg}^{-1}$ dry weight) of $\mathrm{Cl}$ and $\mathrm{Na}$ in the roots of four grapevine cultivars on their own roots and on 'Ramsey' rootstock

\begin{tabular}{|c|c|c|c|c|c|c|c|c|}
\hline & \multicolumn{8}{|c|}{ Root irrigation treatment } \\
\hline & \multicolumn{4}{|c|}{$\mathrm{R}-\mathrm{S}$} & \multicolumn{4}{|c|}{$R+S$} \\
\hline & 'Chardonnay' & 'Sultana' & 'Ruby Cabernet' & 'Shiraz' & 'Chardonnay' & 'Sultana' & 'Ruby Cabe & t' 'Shiraz' \\
\hline \multicolumn{9}{|c|}{ Chloride } \\
\hline Own-root & 107.8 & 210.2 & 107.8 & 128.9 & 235.0 & 309.2 & 145.0 & 197.7 \\
\hline Ramsey & 86.3 & 84.6 & 80.4 & 87.7 & 140.8 & 177.7 & 198.9 & 163.3 \\
\hline \multicolumn{9}{|c|}{$\begin{array}{l}\text { LSD } 33.1(P=0.05) \text { for comparison between different root irrigation treatments with the same or different combinations of rootstock and } \\
\text { cultivar: } 32.6(P=0.05) \text { for comparison between two combinations of cultivar and rootstock receiving the same root irrigation treatment. } \\
\text { Sodium }\end{array}$} \\
\hline Own-root & 67.0 & 110.0 & 77.0 & 101.8 & 159.6 & 219.7 & 126.1 & 130.1 \\
\hline Ramsey & 66.1 & 87.0 & 73.1 & 86.6 & 149.2 & 179.2 & 191.4 & 162.2 \\
\hline
\end{tabular}

foliar irrigation with nonsaline root irrigation supports a rejection of this hypothesis.

In mature vines, Prior et al. (1992a, 1992b) found that over six seasons the effects of salinity on vine growth and the tissue concentrations of $\mathrm{Na}$ and $\mathrm{Cl}$ were cumulative. This suggests that $\mathrm{Na}$ and $\mathrm{Cl}$ were carried over between season in the over-wintering organs of the vine. In immature potted vines, the potential overwintering organs are the root and stem. In the stem (data not presented), the $\mathrm{Na}$ and $\mathrm{Cl}$ concentrations in the treatment combining saline foliar irrigation with nonsaline root irrigation $(\mathrm{F}+\mathrm{S}, \mathrm{R}-$ $\mathrm{S})$ were equivalent to those in the treatment combining nonsaline foliar irrigation with saline root irrigation $(\mathrm{F}-\mathrm{S}, \mathrm{R}+\mathrm{S})$. In the root the $\mathrm{Na}$ and $\mathrm{Cl}$ concentrations in the $\mathrm{F}-\mathrm{S}, \mathrm{R}+\mathrm{S}$ treatment were 1.7 and 1.5 times, respectively, those in the F+S, R-S treatment. In the leaf, the $\mathrm{Na}$ and $\mathrm{Cl}$ concentrations in the $\mathrm{F}+\mathrm{S}, \mathrm{R}-\mathrm{S}$ treatment were 3.0 and 1.9 times those in the $\mathrm{F}-\mathrm{S}, \mathrm{R}+\mathrm{S}$ treatment. This pattern of ion distribution indicates that if given leaf $\mathrm{Na}$ and $\mathrm{Cl}$ concentrations were acquired via foliar uptake then the concentrations of these ions in the over-wintering organs will be less than if the same leaf concentrations were acquired via root uptake. This suggests that the carryover, across seasons, of $\mathrm{Na}$ and $\mathrm{Cl}$ acquired via foliar uptake will be less than that of the same ions acquired via root uptake.

Tissue $\mathrm{Cl}$, $\mathrm{Na}$, and $\mathrm{K}$ concentration. Cultivar differences in the rate of leaf $\mathrm{Na}$ and $\mathrm{Cl}$ uptake under saline irrigation suggest that 'Shiraz' vines would be most at risk of high leaf $\mathrm{Cl}$ and $\mathrm{Na}$ with saline overhead irrigation. With saline under-vine irrigation, 'Sultana' vines would be most at risk of high leaf $\mathrm{Cl}$ and 'Shiraz' of high leaf Na.

Groot Obbink, and Alexander (1973) found that with saline root irrigation only, the $\mathrm{Cl}$ concentration in the leaf petiole of 'Shiraz' was lower than that in 'Sultana'. The present study, where the Cl concentration in the leaf blade was highly correlated with that in the petiole $(r=0.77$, data not presented). Based on this difference Groot Obbink, and Alexander (1973) suggest that 'Shiraz' should have a greater tolerance to $\mathrm{Cl}$ in irrigation water than 'Sultana'. In the present study, with saline foliar and root irrigation, the order was reversed, i.e., the $\mathrm{Cl}$ concentration of 'Shiraz' was greater than that of 'Sultana', which suggests that 'Sultana' should have a greater tolerance to $\mathrm{Cl}$ in irrigation water than 'Shiraz' under overhead irrigation.

The addition of saline root irrigation to saline foliar irrigation did not increase the leaf $\mathrm{Cl}$ concentration and only increased the leaf $\mathrm{Na}$ in the two cultivars with the lowest concentrations of $\mathrm{Na}$. Chloride concentrations in the leaf were at least a $100 \mathrm{mmol} \cdot \mathrm{kg}^{-1}$ dry weight higher than $\mathrm{Na}$. This suggests that uptake of $\mathrm{Na}$ and $\mathrm{Cl}$ via the root pathway may be controlled by the concentrations present in the leaf.

The $\mathrm{Na}$ to $\mathrm{Cl}$ ratios in the saline and nonsaline irrigation water were both unity. The values of the same ratio in the root and stem (between nodes 1 and 4) were 0.9 and 1.7 (Stevens and Harvey, unpublished data). Neither value was affected by the irrigation treatments. In the leaf lamina of the nonsaline control treatment, $\mathrm{Na}$ exclusion reduced the $\mathrm{Na}$ to $\mathrm{Cl}$ ratio to 0.4 . Saline irrigation of the roots increased the ratio to 0.5 and saline irrigation of the foliage increased the ratio to 0.6 . The increase in the value of the ratio with saline root irrigation was associated with a rise in leaf lamina $\mathrm{K}$ concentration, whereas the increase with saline foliar irrigation was associated with a fall in the concentration of $\mathrm{K}$ in the leaf.

The stimulation of leaf growth in the treatment which combined nonsaline foliar irrigation with saline root irrigation was associated with a high leaf $\mathrm{K}$ concentration $\left(436 \mathrm{mmol} \cdot \mathrm{kg}^{-1}\right.$ dry weight as against $266 \mathrm{mmol} \cdot \mathrm{kg}^{-1}$ dry weight in the nonsaline control). In the root, the $\mathrm{K}$ concentration in this treatment was $7 \%$ lower than that in the nonsaline control. These results suggest that the high concentration of $\mathrm{K}$ in the leaf was due to elevated transport from the root.

This association suggests that the exclusion of $\mathrm{Na}$ from the leaves may in part be accomplished by exchanging $\mathrm{K}$ for $\mathrm{Na}$ as the ions move from the root to the shoot. In so far as salinity tolerance is based on a $\mathrm{Na}-\mathrm{K}$ exchange then the enhanced exchange where salt uptake is via the root, suggests that tolerance to soil salinity is based on a different mechanism to that which confers tolerance to saline overhead irrigation.

Our finding that saline root irrigation caused a rise in leaf $\mathrm{K}$ agrees with Hawker and Walker (1978), who worked on Cabernet Sauvignon, and Joolka et al. (1977) who worked with a number of cultivars including 'Sultana', but contrasts with the fall in K concentration found by Prior et al. (1992b) and Downton (1985) who both worked with 'Sultana', and Sourail et al. (1985) who worked with a number of cultivars including 'Sultana'.

With saline root irrigation, the root $\mathrm{Cl}$ concentration in the ownrooted 'Ruby Cabernet' scion was lower than in 'Ramsey' rootstock, whereas in the other three cultivars the root $\mathrm{Cl}$ concentrations in own rooted vines was higher than in those on 'Ramsey' rootstock. The rootstock effect on leaf $\mathrm{Cl}$ was independent of cultivar.

Other nutrients. In the present study, saline root irrigation decreased the leaf concentrations of $\mathrm{K}$ and $\mathrm{Mg}$, and increased leaf $\mathrm{P}$ without reducing growth. We can conclude that salinity induced 
changes in the concentrations of $\mathrm{K}, \mathrm{Mg}$, and $\mathrm{P}$ similar in magnitude to those of the present study, do not affect vine growth.

Implications for the field. The relative effects of root and foliar salt uptake on growth determined under our experimental conditions probably do not translate to the field. In the field, the concentration of salts in the soil is higher than that in the irrigation water. Between irrigations, the processes of evaporation and transpiration concentrate salts in the soil water. In the present study, which was irrigated five times per day, the effect of these processes was probably negligible, however it becomes significant when the irrigation frequency is reduced to once every 14 days. Blesing and Tuffley (1977) and Ayers and Westcot (1985) proposed that after an equilibrium has been reached between salt concentration in the irrigation water and the soil solution, the electrical conductivity of soil water was 3-fold- and 5-fold, respectively, greater than that in the irrigation water. Application of these propositions to irrigation water with a $\mathrm{NaCl}$ concentration of 25 mm gives a corresponding $\mathrm{NaCl}$ concentrations in the soil water of between 75 and $125 \mathrm{~mm}$. Stevens and Harvey (1995) drip irrigated the rootzone of 'Sultana' vines between three and seven times per day for 16 weeks with $60 \mathrm{~mm} \mathrm{NaCl}$. In own-rooted 'Sultana' this caused shoot mass to decline by $42 \%$. In the present trial, increasing the $\mathrm{NaCl}$ concentration of the foliar irrigation from 3 to $26 \mathrm{~mm}$ caused shoot mass to decline by $12 \%$ in own-rooted 'Sultana'. Comparison between the growth losses in these two studies suggests that, after an equilibrium has been established between salt concentration in the irrigation water and the soil solution, the growth loss in field grown vines from salt uptake via the roots would be more than three times that caused by salt uptake via the foliage. However, the allocation of loss against the two pathways is strongly dependent on whether an equilibrium establishes between salt concentration in the irrigation water and the soil solution. In the second season of a field salinity experiment, Prior et al. (1992c) found the ratio of salt concentration in the saturated soil solution to that in the irrigation water was $1: 1$ and rose to $5: 1$ after 6 years of saline irrigation. This suggests under conditions where irrigation water salinity changes from season to season the application of Blesing and Tuffley (1977) or Ayers and Westcot (1985) propositions regarding equilibrium conditions would overestimate the contributions that root uptake of $\mathrm{Na}$ and $\mathrm{Cl}$ make to the growth loss.

Studies of Downton (1985) and Bernstein et al. (1969) have established that 'Ramsey' rootstock excludes chloride from 'Sultana' scions. This property was demonstrated in experiments where only the roots were irrigated. Downton (1985) salinized potted 'Sultana' scions on their own roots and on 'Ramsey' rootstock by irrigating with a $25 \mathrm{~mm}$ mixed cation (sodium dominant) chloride solution. In own-rooted vines the $\mathrm{Cl}$ concentration in the lamina of a leaf sample taken in March was 140 $\mathrm{mmol} \cdot \mathrm{kg}^{-1}$ dry weight and the ratio of the lamina $\mathrm{Cl}$ concentration in scions on 'Ramsey' rootstock to those own-rooted vines was 0.4 . In the present experiment, the $\mathrm{Cl}$ concentration in the lamina of a leaf sample taken in March from own-rooted 'Sultana' vines which had their roots and foliage irrigated with $26 \mathrm{~mm} \mathrm{NaCl}$ was $480 \mathrm{mmol} \cdot \mathrm{kg}^{-1}$ dry weight and the ratio of the lamina $\mathrm{Cl}$ concentration in scions on 'Ramsey' rootstock to those own-rooted vines was 0.9. In the present experiment, foliar uptake was a major pathway for $\mathrm{Cl}$ entry into the vine and as this bypasses the rootstock the reduction in the efficacy of Clexclusion by 'Ramsey' rootstock is to be expected. Under field conditions, the concentration of salts in the soil solution of vines irrigated with $26 \mathrm{mM} \mathrm{NaCl}$ solution by over canopy sprinklers would probably be greater than that in the present experiment. This increase in concentration would increase the proportion of salt entering the vine via the root. For this reason the reduction in the $\mathrm{Cl}$ exclusion efficacy of 'Ramsey' rootstock observed in the present experiment probably overestimates that likely to be observed under field conditions. The degree of overestimation may be minor.

The results of Downton (1985) suggest that increasing the concentration of chloride in the rootzone, and coincidentally the total salt concentration, is associated with a fall in the efficacy of $\mathrm{Cl}$ exclusion by 'Ramsey' rootstock. He found that in vines irrigated with $12.5,25,50$, and $75 \mathrm{~mm} \mathrm{Cl}$ solutions the ratios of lamina $\mathrm{Cl}$ concentration in scions on 'Ramsey' rootstock to those own-rooted vines were $0.3,0.4,0.8$, and 0.7 . In contrast, Bernstein et al. (1969) found that increasing the concentration of chloride in the rootzone from 12 to $50 \mathrm{~mm}$ did not affect the ratios of lamina Cl concentration in 'Sultana' (synonymous with 'Thompson Seedless') scions on 'Ramsey' rootstock to those own-rooted vines, which remained constant at 0.2. However, unlike the study of Downton (1985), that of Bernstein et al. (1969) maintained a constant total salt concentration in the rootzone and produced a variation in the chloride concentration by varying the proportion of chloride and sulphate salts in a $50 \mathrm{~mm}$ mixed cation (sodium dominant) solution. Downton's (1985) model, i.e., an association between increases in the concentrations of chloride and total salt, bears more resemblance to field conditions in the Murray-Darling Basin.

While the use of over-canopy irrigation exposes vines to the risk of salt uptake via the foliage and predisposes the vines to fungal foliage infection (Emmett et al., 1992) this method of irrigation also offers some advantages. Compared with other methods of improved irrigation, e.g., drippers and under-vine sprinklers, overhead sprinklers provide a means of frost protection, have less stringent water filtration requirements because of a larger nozzle diameter, have less emitters to monitor per area covered, allow the use of irrigation to establish cover crops, and have a sprinkler distribution pattern that is insensitive to weed problems. These advantages must be weighed against the increased likelihood of losses to salinity and fungal disease.

In horticultural tree crops, Ehlig and Bernstein (1959) found that the application of saline foliar irrigation at midday caused more leaf damage and greater salt uptake than its application in the evening. Recent findings with barley suggest that variation in climatic parameters other than light, temperature, and humidity may also affect foliar salt uptake. Aragüés et al. (1994) and Gorham et al. (1994) have found that foliar uptake of $\mathrm{Cl}$ and $\mathrm{Na}$ by barley from saline overhead irrigation can be reduced by a short period of irrigation with nonsaline water applied before saline irrigation. These results suggest that salt uptake via foliage from overhead irrigation may be reduced when irrigations immediately follow morning dew or a non-effective rainfall event.

\section{Literature Cited}

Araguiés, R., A. Royo, and S.R. Grattan. 1994. Foliar uptake of sodium and chloride in barley sprinkler-irrigated with saline water: Effect of preirrigation with fresh water. Eur. J. Agron. 3:9-16.

Ayers, R.S. and D.W. Westcot. 1985. Water quality for agriculture. FAO Irr. Drainage Paper no. 29, Rev. 1. FAO : Rome.

Bernstein, L., C.F. Ehlig, and R.A. Clark. 1969. Effect of grape rootstock on chloride accumulation in leaves. J. Amer. Soc. Hort. Sci. 94:584-90.

Blesing, N.V. and J.R. Tuffley. 1977. Study of the potential economic benefits from reduction in salinity of River Murray water. Amdel Rpt. no. 1179. Eng. and Water Supply Dept., Adelaide, South Australia.

Downton, W.J.S. 1977. Influence of rootstocks on the accumulation of chloride, sodium and potassium in grapevines. Austral. J. Agr. Res. 28:879-89. 
Downton, W.J.S. 1985. Growth and mineral composition of the Sultana grapevine as influenced by salinity and rootstock. Austral. J. Agr. Res. 36:425-34.

Ehlig, C.F. 1960. Effects of salinity on four varieties of table grape grown in sand culture. Proc. Amer. Soc. Hort. Sci. 76:323-31.

Ehlig, C.F. and L. Bernstein. 1959. Foliar absorption of sodium and chloride as a factor in sprinkler irrigation. Proc. Amer. Soc. Hort. Sci. 74:661-70.

Emmett, R.W., T.J. Wicks, and P.A. Magarey. 1992. Downy mildew of grapes, p. 90-128. In: J. Kumar, H.S. Chaube, U.S. Singh, and A.N. Mukhopadhyay (eds.). Plant diseases of international importance vol 3. Prentice-Hall, New Jersey.

Francois, L.E. and R.A. Clark. 1979. Accumulation of sodium and chloride in leaves of sprinkler-irrigated grapes. J. Amer. Soc. Hort. Sci. 104:11-13.

Gorham, J., R. Papa and M. Aloy-Lleonart. 1994. Varietal differences in sodium uptake in barley cultivars exposed to soil salinity or salt spray. J. Expt. Bot. 45:895-901.

Groot Obbink, J. and D.McE. Alexander. 1973. Response of six grapevine cultivars to a range of chloride concentrations. Amer. J. Enol. Viticult. 24:65-68.

Hatcher, J.T. and L.V. Wilcox. 1950. Colorimetric determination of boron using carmine. Anal. Chem. 22:567-69.

Hawker, J.S. and R.R. Walker. 1978. The effect of sodium chloride on the growth and fruiting of Cabernet Sauvignon vines. Amer. J. Enol. Viticult. 29:172-76.

Joolka, N.K., J.P. Singh, and A.P. Khers. 1977. Mineral composition of grape as affected by chloride and sulphate salts of sodium in soils. Indian J. Agr. Sci. 47:201-3.

Leece, D.R. and C.C. Short. 1967. A routine procedure for the nutrientelement analysis of peach leaves utilising atomic absorption spectros- copy. New South Wales Dept. of Agr., Div. of Sci. Serv., bul. no. F78. Marschner, H. 1986. Mineral nutrition of higher plants. Academic Press, London.

McKay, N., T. Hillman, and J. Rolls. 1988. Water quality of the River Murray. Murray-Darling Basin Commission, Canberra.

Murphy, J.T. and J.P. Riley. 1962. A modified single solution method for the determination of phosphate in natural waters. Anal. Chim. Acta 27:31-36.

Prior, L.D. and A.M. Grieve. 1985. Overhead sprinkler and salinity effects on grapevines in Sunraysia. Dried Fruit News NS13(1):12-13.

Prior, L.D., A.M. Grieve, and B.R. Cullis. 1992a. Sodium chloride and soil texture interactions in irrigated field grown Sultana grapevines. 1. Yield and fruit quality. Austral. J. Agr. Res. 43:1051-66.

Prior, L.D., A.M. Grieve, and B.R. Cullis. 1992b. Sodium chloride and soil texture interactions in irrigated field grown Sultana grapevines. 2. Plant mineral content, growth and physiology. Austral. J. Agr. Res. 43:1067-83.

Prior, L.D., A.M. Grieve, P.G. Slavich, and B.R. Cullis. 1992c. Sodium chloride and soil texture interactions in irrigated field grown Sultana grapevines. III. Soil and root system effects. Austral. J. Agr. Res. 43:1085-1100.

Sourail, G.F., M.A. Miligi, A.A. Tawfik, and A.M. El-Demerdash. 1985. Effect of saline irrigation on chemical constituents of one-year-old rooted vines: sugars and N.P.K. content. Acta Hort. 158, 169-85.

Stevens, R.M. and G. Harvey. 1995. Effects of waterlogging, rootstock and salinity on $\mathrm{Na}, \mathrm{Cl}$ and $\mathrm{K}$ concentrations of the leaf, and root, and shoot growth of Sultana grapevines. Austral. J. Agr. Res. 46:541-51.

Walker, R.R., E. Törökfalvy, N. Steele Scott, and P.E. Kriedemann. 1981. An analysis of photosynthetic response to salt treatment in Vitis vinifera. Austral. J. Plant Physiol. 8:359-74. 